\title{
Peacekeeping in Turbulent Times
}

\section{Richard Caplan \\ Department of Politics and International Relations, University of Oxford, Oxford, UK}

Whether or not we are witnessing the end of unipolarity, this is clearly a period of flux marked by the rise of emerging powers (notably China, India and Brazil) and the return of geopolitical rivalries (Russia-West tensions), among other potentially far-reaching developments. What are the implications of these developments for the functioning of the United Nations and UN peace operations in particular?

Caution is advisable when speculating about the future. If in 1985 one had been asked to speculate about the future of UN peacekeeping, it is highly unlikely that one would have anticipated the dramatic changes that would impinge on the global order in a few short years - the end of the Cold War, changing patterns of armed conflict, shifting norms of sovereignty-all with significant consequences for UN peace operations. Specifically no one could have foreseen the spectacular expansion in the number, size and scope of UN peace operations that would soon occur.

What is already apparent in the current period, however, is that the cooperation that characterized the early post-Cold War era has been eclipsed by major power rivalry that has at times rendered the Security Council incapable of dealing with severe crises, such as the civil war in Syria. This is nothing new; major power rivalry incapacitated the organization in the past. Of course deadlock can create opportunities for UN peacekeeping but only if the fighting has abated sufficiently and if UN intervention does not threaten major power interests. Neither condition obtains at present in Syria: Russia supports the Syrian government's efforts to achieve a military victory over rebel forces and will not countenance any UN operation that might impede those efforts.

The face of peacekeeping has changed and is continuing to change in important respects. China, historically a minor player in UN peacekeeping, is now the largest troop contributor among the $\mathrm{P} 5$-contributing more troops to UN peacekeeping operations than the P4 countries combined. ${ }^{1}$ China is also the second largest contributor to the UN peacekeeping budget. $^{2}$ Other countries are now playing important roles as well, either as major troop contributors (Ethiopia, Rwanda) or as regional partners and leaders (South Africa, Brazil).

\footnotetext{
1 United Nations. "Summary of Troop Contributing Countries By Ranking", 30 April 2019, https://peacekeeping.un.org/sites/default/files/2-country ranking report.pdf.

2 United Nations. "Effective rates of assessment for peacekeeping operations, 1 January 2019 to 31 December 2021, based on the scale of assessments adopted by the General Assembly in its resolution 73/271and the composition of levels endorsed by the Assembly in its resolution 73/272", UN Doc. A/73/350/Add.1, 24 December 2018, Annex.
} 
When in 2012 SIPRI launched its 'New Geopolitics of Peace Operations' initiative, the underlying assumption was that a shift in power and influence-away from the West and towards emerging powers-was under way that would affect the norms and future conduct of UN peace operations. ${ }^{3}$ Such a shift does indeed appear to be taking place, reflected in some of the trends noted above (among others) and manifesting itself in greater assertiveness on the part of China especially:

--China has pushed back on the use of force with regard to humanitarian intervention, $\mathrm{R} 2 \mathrm{P}$, and robust peacekeeping;

--China has pushed back on the human rights elements of peace operations, challenging the personnel and mandate of individuals responsible for human rights;

--China has pushed back with regard to peacebuilding cum liberal statebuilding, preferring a more narrow developmental model for peacebuilding. ${ }^{4}$

Yet despite this greater assertiveness, by and large a 'fragile consensus' has held among Western and rising powers with respect to UN peacekeeping. ${ }^{5}$ These operations have been established and conducted in accordance with broadly shared norms and principles of peacekeeping, which are reflected in the UN's 'Capstone Doctrine'. ${ }^{6}$ As SIPRI, in the aforementioned study, concluded, 'Although the emerging powers and major [troop- and police-contributing countries] articulate different emphases, they all support the current approaches, concepts and norms in peace operations. ${ }^{7}$

Notwithstanding the divergences noted above, therefore, it seems reasonable to suggest that China, Brazil and other rising powers are buying into the existing order more than they are challenging it. As Michael Swaine, a Senior Fellow at the Carnegie Endowment for International Peace, has observed with respect to China's approach to the established global order generally: 'China's proposed changes to the existing international order...are adjustments of that order only, not radical acts of departure or overturn. ${ }^{8}$ This approach characterises China's stance in relation to UN peacekeeping and is characteristic of the positions of other rising powers as well.

\footnotetext{
${ }^{3}$ Stockholm International Peace Research Institute, "Final Report of the New Geopolitics of Peace Operations".

${ }^{4}$ Royal Institute of International Affairs. "China and the Future of the International OrderPeace and Security", podcast with Rosemary Foot and Roderic Wye, 12 February 2019, https://www.chathamhouse.org/file/china-and-future-international-order-peace-andsecurity\#.

${ }^{5}$ Tardy, "Peace Operations: The Fragile Consensus".

${ }^{6}$ United Nations, United Nations Peacekeeping Operations: Principles and Guidelines.

7 "Final Report of the New Geopolitics of Peace Operations", v.

${ }^{8}$ Swaine, "Chinese Views on Global Governance", 1.
} 
Indeed, one area where one would expect to see more pushback is with regard to the political content of the prevailing liberal peacebuilding agenda. There has been widespread acceptance of the economic content of this agenda among rising powers. After all, this is the same market-oriented context within which these powers have risen and, to a great extent, prospered. The same cannot be said of liberal political institution-building, whose practices of competitive elections, freedom of the press and other media, and the promotion of human rights and the rule of law, among other features, have been tolerated but certainly not embraced by all rising powers. And yet we continue to witness the acquiescence of these powers in the norms and practices associated with political institution-building.

There is also the question of what effect the ascension of Donald Trump to the US presidency has had and will have on UN peacekeeping. The early signs were not promising. Within months of taking office, Trump announced that the US government would be seeking to make cuts of $\$ 1$ billion in funding for UN peacekeeping, representing nearly half of the US's assessed contribution of $\$ 2.2$ billion for the year. Largely in response to US pressure, the UN General Assembly agreed to a $\$ 570$ million cut in the organisation's $\$ 7.87$ billion peacekeeping budget for the year beginning 1 July 2018.

Yet US cost-cutting measures have not amounted to a wholesale attack on UN peacekeeping, and multilateralism more broadly, as many feared it would. Nikki Haley, the US permanent representative to the United Nations appointed by Trump, performed a skilful balancing act, appearing to deliver on US promises to rein in the United Nations while promoting reforms that were in many ways consistent with UN Secretary-General António Guterres's own reform agenda in the area of peace and security. Moreover, it is important to remember that we have been here before. The United States has had a long and complex relationship with the United Nations: the pendulum has swung between globalisation and national interests across the Carter, Reagan/Bush, and Clinton administrations. ${ }^{9}$ We have also seen a scaling back of UN peace operations before, prompted by the seeming failures of the 1990s (notably Bosnia and Herzegovina and Rwanda), and a ramping up of operations subsequently.

The bottom line, then, is that against the backdrop of significant geopolitical developments, no fundamental shift in UN peace operations has taken place yet, nor is one visible on the horizon with regard to the nature of these operations. This despite sometimes fierce debates inside and outside the organization over such fundamental issues as the effectiveness of UN peacekeeping in situations of protracted conflict, the utility of the use of force, the practicability of peacekeeping mandates, and the continuous need for budgetary restraint.

Of course, there are many risks that loom on the horizon. There is the risk that repeated deadlock-over Syria and other major crises-will generate a loss of faith in the United Nations, and in multilateralism more broadly. There is the risk that the challenges arising from non-traditional security threats-violent extremism and international organized crime, among others-may overwhelm UN capacity for effectiveness. And there is the risk that the 'fragile consensus' that underpins UN peacekeeping norms and practices will not hold

\footnotetext{
${ }^{9}$ Luck, Mixed Messages.
} 
indefinitely especially if the challenges that peacekeeping confronts prove to be too daunting. For the foreseeable future, however, there are no major detours ahead.

\section{Disclosure Statement}

No potential conflict of interest was reported by the author.

\section{About the Author}

Richard Caplan is Professor of International Relations at the University of Oxford and the author, most recently, of Measuring Peace: Principles, Practices, and Politics (Oxford University Press, 2019).

\section{Bibliography}

Luck, Edward C. Mixed Messages: American Politics and International Organization 19191990. Washington, DC: The Brookings Institution Press, 2010.

Royal Institute of International Affairs. "China and the Future of the International OrderPeace and Security", podcast with Rosemary Foot and Roderic Wye, 12 February 2019, https://www.chathamhouse.org/file/china-and-future-international-order-peace-andsecurity\#.

Stockholm International Peace Research Institute. "Final Report of the New Geopolitics of Peace Operations", January 2015, https://www.sipri.org/sites/default/files/2016-03/NGPFinal-Report 0.pdf.

Swaine, Michael D. "Chinese Views on Global Governance since 2008-9: Not Much New", China Leadership Monitor no. 49 (Winter 2016), http://www.hoover.org/research/chineseviews-global-governance-2008-9-not-much-new.

Tardy, Thierry. "Peace Operations: The Fragile Consensus", SIPRI Yearbook 2011. Stockholm: Oxford University Press, 2011.

United Nations. Department of Peacekeeping Operations and Department of Field Operations. United Nations Peacekeeping Operations: Principles and Guidelines (2008), https://www.un.org/en/peacekeeping/documents/capstone eng.pdf.

United Nations. "Effective rates of assessment for peacekeeping operations, 1 January 2019 to 31 December 2021, based on the scale of assessments adopted by the General Assembly in its resolution 73/271and the composition of levels endorsed by the Assembly in its resolution 73/272", UN Doc. A/73/350/Add.1, 24 December 2018, Annex.

United Nations. "Summary of Troop Contributing Countries By Ranking", 30 April 2019, https://peacekeeping.un.org/sites/default/files/2-country ranking report.pdf. 